УДК 347.9:342.7-053.2(477)]:341.645.5(4)]](045)

DOI https:// doi.org/10.32837/yuv.v0i1.1661

М. Корнієнко,

магістр права, практикуючий юрист

\title{
ПРИНЦИП ДОТРИМАННЯ НАЙКРАЩИХ ІНТЕРЕСІВ ДИТИНИ ТА ЙОГО ЗАСТОСУВАННЯ У ЦИВІЛЬНОМУ СУДОЧИНСТВІ УКРАЇНИ
}

Визначальним принципом, що застосовується у вирішенні питань щодо дітей, є принцип дотримання найкращих інтересів дитини (англ. - the best interests of the child). Попри частий вжиток цієї правової категорії, іiі зміст залишається недостатньо визначеним. Питанням нормативного закріплення, тлумачення та сучасного визначення цього поняття, науковим і судовим підходам присвячена наша стаття.

Питанням найкращих інтересів дитини та відповідному принципу присвячені наукові роботи Ж. Петрочко, Ю. Василькової, Л. Волинець, С. Журила, О. Мельника, С. Фурси та інших фахівців.

Принцип дотримання найкращих (найвищих) інтересів дитини закріплений у низці нормативно-правових актів державного та міжнародного рівнів.

Перші згадки про цей принцип зафіксовано в Декларації прав дитини 1959 р. (п. 2). Згодом таку засаду було закріплено в низці міжнародно-правових актів, зокрема в Конвенції про ліквідацію всіх форм дискримінації щодо жінок 1979 р., Конвенції про цивільно-правові аспекти міжнародного викрадення дітей 1980 р., Конвенції про захист дітей і співробітництво в галузі міжнародного усиновлення 1993 р., Конвенції про юрисдикцію, право, що застосовується, визнання, виконання та співробітництво щодо батьківської відповідальності та заходів захисту дітей 1996 р. [15, с. 2].

Основним нормативно-правовим актом, який закріплює принцип дотри- мання найкращих інтересів дитини та $€$ чистиною національного законодавства України, є Конвенція ООН про права дитини (далі - Конвенція), прийнята 20 листопада 1989 р. та ратифікована Верховною Радою Української РСР 27 лютого 1991 р.

Згідно з положеннями ст. $3 \mathrm{KoH}-$ венції в усіх діях щодо дітей незалежно від того, здійснюються вони державними чи приватними установами, що займаються питаннями соціального забезпечення, судами, адміністративними чи законодавчими органами, першочергова увага приділяється якнайкращому забезпеченню інтересів дитини [1].

Відповідно до ст. 18 Конвенції батьки або у відповідних випадках законні опікуни несуть основну відповідальність за виховання і розвиток дитини. Найкращі інтереси дитини є предметом їх основного піклування [1].

Цей принцип відображений у низці інших статей Конвенціі, зокрема ст. 9, 20, 21, 37 та 40. Загалом у Конвенції поняття «найкращі інтереси дитини» згадується дев'ять разів [14, с. 70].

Комісар Ради Європи 3 прав людини Томас Хаммарберг у своїй промові у 2008 р. зазначив, що у першому ж проекті Конвенції про права дитини ООН, наданим урядом Польщі у 1978 р., було чітко висловлено позицію щодо включення принципу якнайкращого забезпечення інтересу дитини в основний текст і надання йому вагомої позиції [16, с. 350]. 
Сімейний кодекс (далі - СК) України закріплює принцип дотримання найвищих інтересів дитини. Згідно 3 положеннями ч. 2 ст. 207 СК України усиновлення дитини провадиться у iï найвищих інтересах для забезпечення стабільних і гармонійних умов ii життя [2].

Закон України «Про охорону дитинства» визначає охорону дитинства в Україні як стратегічний загальнонаціональний пріоритет, що має важливе значення для забезпечення національної безпеки України, ефективності внутрішньої політики держави, і з метою забезпечення реалізації прав дитини на життя, охорону здоров'я, освіту, соціальний захист, всебічний розвиток і виховання в сімейному оточенні встановлює основні засади державної політики у цій сфері, що грунтуються на забезпеченні найкращих інтересів дитини [3].

Ст. 1 вказаного Закону визначено, що забезпечення найкращих інтересів дитини - це дії та рішення, спрямовані на задоволення індивідуальних потреб дитини відповідно до іï віку, статі, стану здоров'я, особливостей розвитку, життєвого досвіду, родинної, культурної та етнічної належності, які враховують думку дитини, якщо вона досягла такого віку і рівня розвитку, що може іï висловити [3].

Таким чином, у законодавстві лише закріплюється обов'язок дотримання найкращих (найвищих) інтересів дитини, однак нормативного визначення цього поняття немає. 3 огляду на відсутність законодавчого визначення поняття найкращих інтересів дитини звернемося до наукових підходів і поглядів провідних учених.

С.Я. Фурса під інтересами дитини пропонує розуміти забезпечення умов, необхідних для повноцінного фізичного, психічного і духовного розвитку дитини. Аналізуючи процес дотримання найвищих інтересів дитини у процедурі усиновлення, авторка зазначає, що дотримання інтересів дитини - це головна мета усиновлення в нашій кра- їні. Усиновлення дитини проводиться у іï найвищих інтересах для забезпечення стабільних і гармонійних умов іiі життя. Отже, інтереси дітей в інституті усиновлення є основною метою, заради якої він введений [12, с. 538-539, 542].

Як зазначає Ж.В. Петрочко, забезпеченням найкращих інтересів дитини $є$ задоволення іiі індивідуальних потреб відповідно до віку дитини, статі, стану здоров'я, особливостей розвитку, життєвого досвіду, родинної, культурної та етнічної належності з урахуванням думки дитини [14, с. 71].

О.В. Мельник вважає, що найкращі інтереси можуть бути ототожнені 3 поняттям благополуччя, яке охоплює матеріальну, духовну, емоційну, психічну та інші складові частини [13, с. 75].

Як можна помітити, науковці наповнюють поняття найвищих інтересів дитини доволі широким змістом. Із наведених доктринальних визначень вбачається, що найвищі інтереси дитини $€$ комплексним поняттям, яке включає в себе низку елементів.

Органом, котрий найбільш часто має справу з поняттям найкращих інтересів дітей, оцінює степінь дотримання цих інтересів і приймає визначальні для дітей і їхніх батьків рішення, є суд.

Найчастіше національні суди застосовують принцип дотримання найкращих інтересів дитини у розгляді справ про позбавлення батьківських прав або про визнання батьківства, про усиновлення, визначення місця проживання дитини, надання доступу до спілкування та / або усунення перешкод у спілкуванні з дитиною, забезпечення побачень із дитиною батькам або близьким родичам, у розгляді заяв, поданих на підставі Конвенції про цивільно-правові аспекти міжнародного викрадення дітей 1980 р. тощо.

Перш ніж переходити до аналізу практики українських судів, вважаємо за необхідне звернутися до усталених підходів Європейського суду з прав людини (далі - ЄСПЛ), практика якого $€$ визначальною для судової практики країн Європи. 
Одним із найбільш обговорюваних i застосовуваних рішень ЄСПЛ $€$ рішення у справі M.C. проти України (заява № 2091/13) від 11 липня 2017 р.

У цьому рішенні ЄСПЛ, установивши порушення ст. 8 Конвенціі, консолідував ті підходи і принципи, що вже публікувалися у попередніх його рішеннях і зводяться до необхідності першочергового врахування інтересів дитини, які мають перевагу над інтересами батьків. Визначення найкращих інтересів дитини потребує детального вивчення ситуаціі, урахування різноманітних чинників, що можуть вплинути на інтереси дитини, дотримання справедливої процедури у вирішенні спірного питання для всіх сторін.

У $\$ 75$ рішення по вказаній справі ЄСПЛ зазначив, що сьогодні існує широкий консенсус, у т. ч. в міжнародному праві, на підтримку ідеї про те, що в усіх рішеннях, які стосуються дітей, забезпечення їхніх найкращих інтересів повинно мати першочергове значення. Найкращі інтереси дитини залежно від ix характеру та серйозності можуть перевищувати інтереси батьків [4].

$\mathrm{V}$ вирішенні питань, що стосуються iï життя, дитині, здатній сформулювати власні погляди, має бути забезпечено право вільно висловлювати ці погляди 3 усіх питань, які іiі стосуються, причому поглядам дитини приділяється належна увага згідно з ї віком і зрілістю [4].

Аналогічний підхід ЄСПЛ висловлений у $\$ 54$ рішення у справі Xaнm проти України (заява № 31111/04) від 07 грудня 2006 р., у якому зазначено, що між інтересами дитини й інтересами батьків повинна існувати справедлива рівновага i, дотримуючись такої рівноваги, особлива увага має приділятися найважливішим інтересам дитини, які за своєю природою та важливістю мають переважати над інтересами батьків [5].

Варто також звернути увагу на рішення ЄСПЛ у справах Мамчур проти України та Савіни проти України, в яких було визнано порушення
Україною ст. 8 Конвенції - права на повагу до приватного i сімейного життя, в т. ч. Й через недотримання принципу забезпечення найкращих інтересів дитини.

У $\$ 100$ рішення у справі Мамчур проти України (заява № 10383/09) від 16 липня 2015 р. ЄСПЛ зазначив, що при визначенні основних інтересів дитини у кожному конкретному випадку необхідно враховувати дві умови: по-перше, у якнайкращих інтересах дитини буде збереження іï зв'язків із сім'єю, крім випадків, коли сім'я виявляється особливо непридатною або явно неблагополучною, по-друге, у якнайкращих інтересах дитини буде забезпечення іï розвитку у безпечному, спокійному та стійкому середовищі, що не є неблагополучним [7].

У справі Савіни проти України (заява № 39948/06) від 18 грудня 2008 р. ЄСПЛ вказує, що право батьків і дітей бути поряд один з одним становить основоположну складову частину сімейного життя і що заходи національних органів, спрямовані перешкодити цьому, є втручанням у права, гарантовані ст. 8 Конвенції [6].

У $\$ 52$ вказаного рішення ЄСПЛ зазначив, що, з іншого боку, держава має позитивний обов'язок вживати виважених і послідовних заходів зі сприяння возз'єднанню дітей зі своїми біологічними батьками, дбаючи при досягненні цієї мети про надання ім можливості підтримувати регулярні контакти між собою та, якщо це можливо, не допускаючи розлучення братів i сестер [6].

Всі зазначені рішення ЄСПЛ застосовуються національними судами України при вирішенні сімейних справ у порядку цивільного судочинства. Деякі з рішень ЄСПЛ стають поворотними та істотно змінюють практику, що складалася в Україні. Зокрема, такими поворотними рішеннями стали рішення у справах M.C. проти України та Xант проти України, в яких була проголошена перевага прав дитини над правами ї̈ батьків. 
Нижче розглянемо декілька прикладів правових позицій Верховного Суду щодо тлумачення категорії найкращих інтересів дитини та застосування цього принципу при вирішенні сімейних справ.

У постанові у справі № 712/ 10623/17 від 4 липня 2018 р. Велика Палата Верховного Суду зазначила, що положення про рівність прав та обов'язків батьків у вихованні дитини не може тлумачитися на шкоду інтересам дитини. Кожна справа потребує детального вивчення ситуації, врахування різноманітних чинників, які можуть вПлинути на інтереси дитини, у т. ч. іiі думки, якщо вона відповідно до віку здатна сформулювати власні погляди [8].

У зазначеній справі батько не надавав дитині згоди на виїзд за кордон на навчання. Мати дитини звернулася до суду з позовною заявою про надання дозволу на виїзд дитини за кордон без згоди та супроводу батька на підставі судового рішення на час навчання дитини.

Батько заперечував проти задоволення позову та зазначав, що вимога матері суперечить чинному законодавству, яке визначає рівність прав та обов'язків батьків у вихованні дитини, а це може призвести до фактичного позбавлення батька дитини передбаченої законодавством можливості брати участь у їі вихованні та можливості спілкування з нею.

Суди трьох інстанцій визначили, що виїзд дитини за кордон 3 метою навчання та здобуття освіти відповідає ii найкращим інтересам. Тож правам дитини має бути надана перевага перед правами батька. На підставі вищезазначеного позов матері був задоволений.

Схожим є підхід, висловлений у постанові Касаційного цивільного суду у справі № 534/1578/18 від 18 березня 2020 р. У вказаній постанові зазначено, що аналіз норм права та практики ЄСПЛ дає підстави для висновку про те, що рівність прав батьків $є$ похідною від прав та інте- ресів дитини на гармонійний розвиток і належне виховання, насамперед повинні бути визначені інтереси дитини у ситуації спору, а вже тільки потім права батьків. Будь-які спори між батьками, у які залучена дитина і які вирішуються органом опіки та піклування або судом, завдають шкоди їі фізичному та розумовому розвитку i суперечать принципу забезпечення найкращих інтересів дитини [9].

У постанові у справі № 372 / $3324 / 17$ від 14 квітня 2020 р. Касаційний цивільний суд зазначив, що дитина $€$ найбільш вразливою стороною в ході будь-яких сімейних конфліктів, судовий розгляд сімейних спорів, у яких зачіпаються інтереси дитини, є особливо складним. Дитина є суб'єктом права і, незважаючи на незначний вік, неповну цивільну дієздатність, має певний обсяг прав. Одними з основних іï прав є право висловлювати свою думку та право на врахування думки щодо питань, які стосуються їі життя [11].

$\mathrm{y}$ постанові по справі № $341 /$ $793 / 17$ від 25 березня 2020 р. Касаційний цивільний суд, розглядаючи справу про визначення місця проживання дитини, вказав, що виховання дитини має спрямовуватися на розвиток іï особистості, поваги до прав, свобод людини і громадянина, мови, національних історичних і культурних цінностей українського та інших народів, підготовку дитини до свідомого життя у суспільстві в дусі взаєморозуміння, миру, милосердя, забезпечення рівноправності всіх членів суспільства, злагоди та дружби між народами, етнічними, національними, релігійними групами. Міжнародні та національні норми не містять положень, які б наділяли будь-кого з батьків пріоритетним правом на проживання 3 дитиною. При визначенні місця проживання дитини судами необхідно крізь призму врахування найкращих інтересів дитини встановлювати та надавати належну правову оцінку всім обставинам справи, що мають значення для правильного 


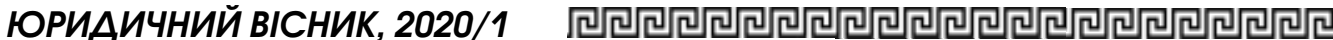

вирішення спору. Отже, при розгляді справ щодо місця проживання дитини суди насамперед мають виходити 3 інтересів самої дитини, враховуючи сталі соціальні зв'язки, місце навчання, психологічний стан тощо, а також дотримуватися балансу між інтересами дитини, правами батьків на виховання дитини й обов'язком батьків діяти в $\dddot{11}$ інтересах [10].

Аналіз актуальної практики дає підстави зробити висновок, що сьогодні Верховний Суд здебільшого справ грунтовно та справедливо оцінює обставини справи, на підставі здійсненого аналізу визначає, що відповідає найкращим інтересам дітей, і приймає обгрунтовані рішення, за необхідності виправляючи помилки, допущені судами попередній інстанцій.

Принцип дотримання найкращих інтересів дитини широко застосовується судами та іншими органами державної влади у вирішенні питань щодо дітей. Водночас законодавчого та загальноприйнятого визначення поняття «найкращі інтереси дитини» сьогодні не вироблено. Більше того, в законодавстві України вживаються різні назви цієї правової категорії - «найкращі інтереси» та «найвищі інтереси».

3 огляду на відсутність нормативного визначення тлумачення цього поняття здебільшого $є$ прерогативою судів, котрі розглядають сімейні спори та вирішують питання щодо інтересів дітей. Основою судового тлумачення поняття «найвищі інтереси дитини» $€$ практика ЄСПЛ, який надає широке визначення цього поняття та залишає для національних судів свободу розсуду при встановленні того, що відповідає найкращим інтересам дитини у кожному конкретному випадку.

На наш погляд, необхідним є закріплення поняття найкращих інтересів дитини в національному законодавстві, зокрема у ст. 1 Закону України «Про охорону дитинства». Крім того, вважаємо за доцільне уніфікувати положення законодавства та вживати загальноприйнятий термін «найкращі інтереси дитини», не замінюючи його аналогом «найвищі».

Аналіз актуальної практики Верховного Суду дає підстави стверджувати, що на рівні суду касаційної інстанції існує правильне та розгорнуте розуміння принципу дотримання найвищих інтересів дитини, що відповідає практиці ЄСПЛ і положенням міжнародних актів. Водночас внесення необхідних змін до законодавства забезпечить правильне застосування цього принципу судами нижчих інстанцій, органами опіки та піклування та іншими державними органами, які приймають рішення у справах щодо дітей.

Дослідження автора присвячено поняттю «найкращі інтереси дитини» як основній правовій категорії, що застосовується у розгляді справ щзодо дітей. Автором проаналізовані положення міжнародних нормативно-правових актів $i$ законодавчих актів України, які закріплюють принциип дотримання найкращих інтересів оитини. Зокрема, норми Конвениіі ООН «Про права дитини», Сімейного кодексу Украйни та Закону України «Про охорону дитинства». Автор звернувся до наукових підходів до визначення поняття найкращуих (найвищих) інтересів дитини та навів тлумачення декількох провідних вчених. Значна частина статті присвячена судовому тлумаченню досліджуваного поняття, а саме практиці Європейського суду з прав людини. Автором проаналізовані підходи до визначення понятmя найкращих інтересів у рішеннях по справах «М.C. проти України», "Хант проти України», «Савіни проти України» та «Мамчур проти України». У статті виокремлені категорії справ, у яких українські суди найбільш часто звертаються до принциипу дотримання найкращuх інтересів дитини й у яких цеей приниип є визначальним. Виділені підходи Верховного Суду до визначення поняття найкращих інтере- 
сів оитини, проаналізовані рішення Верховного Суду у сімейних спорах, ухвалені протягом 2018-2020 рр. У висновках автор наводить свої узагальнення щодо дослідженої проблематики та пропонуе иляхи вдосконалення чинного законодавства. Зокрема, запропоновано доповнити cm. 1 Закону України «Про охорону дитинства» визначенням поняття «найкращі інтереси дитини». На думку автора, закріплення визначення цього поняття на законодавчому рівні матиме позитивний вплив на правозастосування загалом $i$ судову практику зокрема. Крім того, пропонується уникати вживання поняття «найвищі інтереси» та використовувати «найкращі інтереcu dumuru» (the best interests of the child), яке передбачено Конвенцією ОО про права дитини.

Ключові слова: цивільний процес, права дитини, найкращі інтереси дитини, Європейський суд з прав людини.

Korniienko M. Principle of the best interests of the child and its application in civil proceedings of Ukraine

The author's research is devoted to the concept of "the best interests of the child» as the main legal category used in cases concerning children. The author analyzes the provisions of international regulations and legislative acts of Ukraine, which enshrine the principle of the best interests of the child. In particular, the provisions of the UN Convention on the Rights of the Child, the Family Code of Ukraine and the Law of Ukraine "On Childhood Protection." The author turned to scientific approaches to defining the concept of the best (the highest) interests of the child and gave an explanation to several leading scientists. Much of the article is devoted to the judicial interpretation of the concept of the best interests of the child, namely the approaches of the European Court of Human Rights. The author analyzes the approaches to defining the concept of best interests in decisions on the cases of M.S. v. Ukraine, Hunt v. Ukraine, Savina v. Ukraine and Mamchur v. Ukraine. The article highlights the categories of cases in which Ukrainian courts most often refer to the principle of the best interests of the child, and in which this principle is decisive. The author highlights the approaches of the Supreme Court to define the best interests of the child in family cases considered during 2018-2020. In the conclusions, the author provides her generalizations on the researched issues and suggests ways to improve the current legislation. In particular, the author proposed to supplement Art. 1 of the Law of Ukraine "On Childhood Protection" by defining the concept of "the best interests of the child". According to the author, consolidating the definition of this concept at the legislative level will have a positive impact on law enforcement in general and judicial practice in particular. In addition, the author proposes to avoid the use of the concept of "the highest interests of the child" and to use the concept of "the best interests of the child", which is provided by the Convention on the Rights of the Child.

Key words: civil process, rights of the child, best interests of the child, European Court of Human Rights.

\section{Література}

1. Конвенція ООН про права дитини віة 20 rucmonada 1989 p. URL: http:// zakon3.rada.gov.ua/laws/show/995_021.

2. Сімейний кодекс Украӥни : Закон України від 10 січня 2002 р. № 2947-III. URL: https: / / zakon.rada.gov.ua/laws / show/2947-14.

3. Про охорону дитинства : Закон України від 26 квітня 2001 р. № 2402-III. URL: https: / / zakon.rada.gov.ua/laws / show/2402-14.

4. Решение Европейского суда по правам человека по делу М.С. против Украины от 11 июля 2017. Переклад Харківської правозахисної групu. URL: http: / / khpg.org / index.php?id=1514368384.

5. Рішення Європейського суду з прав людини у справі Хант проти Укра- 


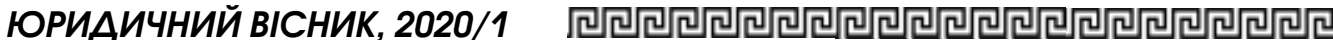

їни від 7 грудня 2006 p. URL: https:// zakon.rada.gov.ua/laws/show/974_126

6. Рішення Європейського суду з прав людини у справі Савіни проти України від 18 грудня 2008 p. URL: https:// zakon.rada.gov.ua/laws/show/974_454

7. Рішення Європейського суду з прав людини у справі Мамчур проти України від 16 липня 2015 p. (остаточне від 16 жовтня 2015 p.). URL: https: / / zakon.rada.gov.ua/ laws / show/974_a93.

8. Постанова Великої Палати Верховного Суду у справі № 712/10623/17 від 4 липня 2018 p. URL: http: // reyestr.court.gov.ua/ Review/ 75266002

9. Постанова Касаційного иивільного суду у справі № 534 / 1578/18 від 18 березня 2020 p. URL: http: // reyestr.court.gov.ua/ Revier/88376149.

10. Постанова Касаційного цивільного суду у справі № 341/793/17 від 25 березня 2020 p. URL: http: // reyestr.court.gov.ua/ Review/88461111.

11. Постанова Касаційного цивільного суду у справі № 372/3324 / 17 від 14 квітня
2020 p. URL: http:// reyestr.court.gov.ua/ Review/88815291.

12. Сімейний кодекс Украӥни: науково-практичний коментар / за заг. ред. С.Я. Фурси. Київ : Видавець Фурса С.Я., 2008. 1248 c

13. Мельник О.В. Правове поняття та характерні особливості інтересів дитини при усиновленні. Jurnalul juridic national: teorie și practică. Кишинiв, 2015. № 4 (14). C. 73-76.

14. Петрочко Ж.В. Найкращі інтереси дитини: сутність $і$ иляхи забезпечення. "Наукові записки» Ніжинського державного університету ім. М. Гоголя. Психологопедагогічні науки. 2014. № 3. С. 70-74.

15. Тубольиева Я.С. Забезпечення найкращих інтересів дитини при розгляді судом справ про усиновлення. Теорія і практика правознавства. 2018. Bun. 2 (14). C. 1-14.

16. Ольхова А.В. Принцип якнайкращого забезпечення інтересів дитини у міжнародному гуманітарному праві. Часопис Київького університету права. 2013. № 1. C. 348-352. 